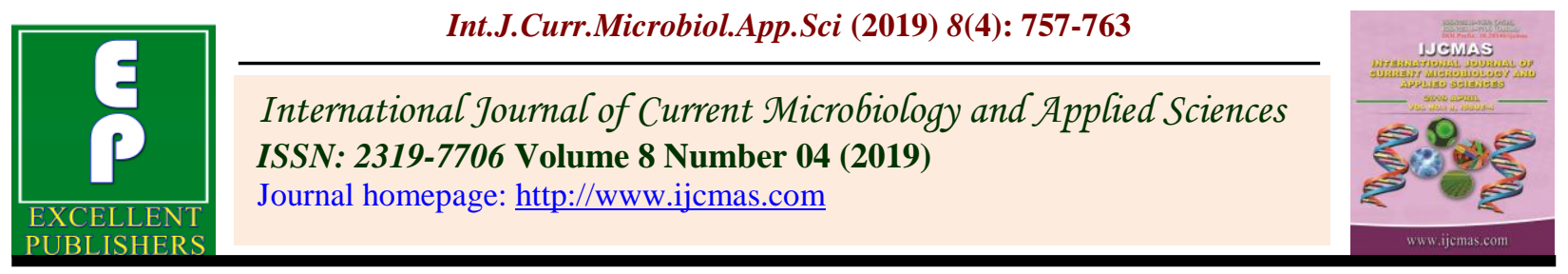

Original Research Article

https://doi.org/10.20546/ijcmas.2019.804.083

\title{
Technological Study on Project Management Activities of Epc Solar Pv Power Plant
}

\author{
K.H. Gohil ${ }^{1}$, V.V. Modi ${ }^{2}$, Gora Alok ${ }^{3 *}$, N.N. Desai ${ }^{2}$, Ramesh Harajibhai Chaudhari ${ }^{2}$, \\ V.M. Modi ${ }^{2}$ and Hitesh Chaudhary ${ }^{2}$ \\ ${ }^{1}$ Energy System \& Technology (Focused on Solar Energy, PDPU, Gandhinagar, India \\ ${ }^{2}$ College of Renewable Energy and Environmental Engineering, SDAU, S.K. Nagar, India \\ ${ }^{3}$ Department of Agricultural Engineering, C.P. College of Agriculture, \\ SDAU, S.K. Nagar, India \\ *Corresponding author
}

\section{A B S T R A C T}

Keywords

Project

management,

Engineering

procurement and

Construction, Solar

PV, Power plant

Article Info

Accepted:

07 March 2019

Available Online:

10 April 2019
This research paper examined the techniques of project management used in development of solar photovoltaic power plant. The background of the project described its planning, execution, operation \& maintenance. Critical success factor for the project implementation were identified presenting an overview of project structure, methods, risk, etc. The study depicted the different barriers for solar power projects development in India. The research work was based on the project management activities of 40MW (AC) Solar PV Power Plant at Gujarat Solar Park, Charanka. The study analyzed all execution activities during the construction phase of project and identified how well management of project improves the performance of solar PV power plant.

\section{Introduction}

Indian is becoming one of the leading nations in solar energy by taking steps towards implementing large MW scale solar power projects and it poised to position itself as a one of the world's major solar producer as well as a manufacturing hub for solar power plants. The effective utilization of India's solar potential will lie in the successful implementation of the Jawaharlal Nehru National Solar Mission (JNNSM). This would also mitigate the international pressure with regard to the emission reductions. Ministry of
New and Renewable Energy (MNRE) has set ambitious target of 100000 MW Solar Power by the year 2022. To achieve this target, Solar Energy Corporation of India (SECI) under Jawaharal Nehru National Solar Mission Phase II Batch IV Tranche-I (the "Scheme") invited a Request for Selection for setting up 250 MW solar PV power plant at Gujarat Solar Park, Charanka. Gujarat Industries Power Company Limited (GIPCL) has participated in SECI's tender for solar power project to be established at Gujarat Solar Park, Charanka. GIPCL emerged as successful Bidder for Plot No.1 and Plot 
No.3, i.e. 2x40 MW Solar Power Project(s). Completion Schedule (COD with SECI) of the project was 242 days from the date of LOI. The LOI date was 17/10/2016.

For each project of $40 \mathrm{MW}$, the AC capacity of the project shall be $40 \mathrm{MW}$ (AC) at GETCO end substation. Each 40MW (AC) shall be considered separate project. This report was based on the performance management of 40MW power plant for plot no. 3. The Vikram Solar Pvt. Ltd. (EPC Contractor Company) shall give 46.8 MW DC capacities for this site.

\section{Materials and Methods}

The study was carried out at GIPCL's 40MW solar photovoltaic grid connected power plant at Village: Charanka of Patan District, Gujarat State. This site has the entire prerequisite to be termed as high potential site for solar installation. There was unused land available with GIPCL within Charanka at one site. The location of the site was shown in the map below in Figure 1.

\section{Project location and site parameters}

\section{Project overview}

DC Plant Capacity: 46.76 MW DC / 40 MW $\mathrm{AC}$

Land: 180 Acres

Structures: 7250 No. Hot Dip Galvanized (HDGI)

Modules: 146260 No. Polly 320 Wp 72 cells by Vikram Solar

Invertors: 32 (1250kW) HIVERTER 1.25 MW new HITACHI

\subsection{MVA Transformer:16}

Switchyard: Double Bay as per GETCO requirement

Annual Energy Production: 81483 MWh/year

\section{Site energy estimation}

Power generation in term of $\mathrm{kWh}$ for the proposed site at Gujarat Solar Park, Charanka was calculated using PVSyst Software. A standard radiation data for last 25 years retrieved from NASA was considered for energy generation estimation. Detailed analysis of design parameters and resultant output along with stage wise losses were carried out using this software. The simulation was done for a solar PV power plant of 40MW AC capacity. The reports of "simulation parameters", "main results" and loss diagram were reproduced below in Figure 2.

As per the simulation, there were 20 modules of $320 \mathrm{Wp}$ connected in series with 7313 connected in parallel strings covering total module area of approximately $280791 \mathrm{~m}^{2}$ having a total of 146260 numbers of modules. Inverter characteristics and loss factors was also taken into consideration to design the solar PV system purpose with an objective of providing unlimited load to the power plant user. As per NASA radiation data, the main results show annual energy production of $81483 \mathrm{MWh} /$ year with specific production of $1740 \mathrm{kWh} / \mathrm{kWp} /$ year and performance ratio of 76.4\%. As expected, maximum generation was observed in summer months with reasonably good generation in winter.

The loss diagram also shows that the final output has been calculated considering sufficiently the various kinds of losses encountered by the power plant in a practical condition in field. However, other configurations were also possible depending on the detailed and final design.

\section{Project management process}

The figure 3 shows the time required for the different activities of Solar PV Power Plants. 
All the activities were performed as parallel to each other from Starting months of project to the closure of the project.

Before starting the execution of the installation of solar PV system, below mentioned steps to be followed:

Planning and scheduling of the 3M's (Man power, Machinery / Equipment and Material): Developer/Owner/Contractor has to plan and schedule the $3 \mathrm{M}$ 's i.e. Man, Machinery and Material required for the system installation as and when required. This can be done details in MS project or manually also.

The detail planning and scheduling of 3m's can be done as; Identifying different activities and its sequence, Starting and completion date of each activities, Fixing date of manpower of different type of activities like civil, mechanical and electrical as per its sequence and starting and completion time, Identifying time of requirement of different materials and machineries and its quantities.

\section{Project monitoring}

Project monitoring was done by following:

Daily Tracking of Activities

Analyzing daily data

An S-curve was defined as: "A display of cumulative costs, labor hours or other quantities plotted against time. The name derives from the $\mathrm{S}$-like shape of the curve, flatter at the beginning and end and steeper in the middle, which was typical of most projects. The beginning represents a slow, deliberate but accelerating start, while the end represents a deceleration as the work runs out. Results and Discussion

\section{Challenges and solutions in project design and engineering}

The project faced specific challenges related to the desert conditions at the site such as high temperature, sandy loose soil, sand storms, water quality and scarcity. Vikram Solar Pvt. Ltd. (EPC Contractor Company) addressed these challenges with suitable design and engineering applications as well as selecting suitable components.

High temperature of PV Module: EPC Contractor Company selected PV modules with a low temperature coefficient to optimize energy generation of the solar plant. EPC Contractor Company had conducted a comparative assessment of module parameters including temperature coefficient, comparative generation analysis and track record under similar operating conditions.

Sandy loose soil and sand storms: The soil type of project area was loamy sandy with low soil bearing capacity (14 ton/square meter at 1.5 meter depth and 15 ton/square meter at 3 meter depth). Dust storms were common in the region during summer (average annual frequency was 10 per year). EPC Contractor Company opted for a composite piling type foundation for the project after assessment of geo-technical parameters of the site. In addition to providing adequate strength, EPC Contractor Company achieved high installation speed, less time for curing and low cost of installation. All relevant international quality codes 9 and standards were followed during the design stage. Later, pull out tests were conducted to test the foundations. They showed that the foundation strength was up to 12.5 tonnes, making it extremely robust with the ability to withstand high wind speeds of up to $170 \mathrm{~km} / \mathrm{h}$.

Saline groundwater: The ground water at the 
project site was saline. The $\mathrm{pH}$ of surface water was 7.67. This could corrode the metal structures of the project. In general, hot dip galvanization was done with 70 micron thickness to avoid any corrosive impact of water. EPC Contractor Company used hot dip galvanized structures with 80 micron thickness, to ensure sufficient protection for a longer life.

Table.1 Location of site

\begin{tabular}{|c|c|c|c|c|}
\hline Parameter & Location & Parameter & Location & $\begin{array}{l}\text { Distance } \\
(\mathbf{k m})\end{array}$ \\
\hline Site Location & $\begin{array}{l}\text { Gujarat } \\
\text { Solar Park }\end{array}$ & Nearest Urban area & Patan & 122 \\
\hline Tehsil & Charanka & $\begin{array}{l}\text { Nearest National } \\
\text { Highway }\end{array}$ & NH 15 & 15.5 \\
\hline District & Patan & Nearest State Highway & SH 10 & 129 \\
\hline Latitude & $\begin{array}{l}23^{\circ} 54^{\prime} \\
26.45^{\prime \prime} \mathrm{N}\end{array}$ & $\begin{array}{l}\text { Nearest Railway } \\
\text { Station }\end{array}$ & Palanpur & 172 \\
\hline Longitude & $\begin{array}{l}71^{\circ} 12^{\prime} \\
4.79^{\prime \prime} \mathrm{E}\end{array}$ & $\begin{array}{l}\text { Nearest Domestic } \\
\text { Airport }\end{array}$ & Ahmedabad & 244 \\
\hline Elevation (m) & 25 & $\begin{array}{l}\text { Nearest International } \\
\text { Airport }\end{array}$ & Ahmedabad & 244 \\
\hline Area (acre) & 180 & Nearest Port & Kandla & 176 \\
\hline
\end{tabular}

Table.2 Completion schedule (COD with SECI) of $40 \mathrm{mw}$ solar power project of plot No.3 at Gujarat solar park

\begin{tabular}{|c|c|c|c|c|c|c|c|c|c|c|c|c|c|c|c|c|c|c|}
\hline Days & $\mathbf{0}$ & 20 & 40 & 60 & 80 & 100 & 120 & 140 & 160 & 180 & 200 & 220 & 240 & 260 & 280 & 300 & 320 & 340 \\
\hline Wassue of LOI & & & & & & & & & & & & & & & & & & \\
\hline $\begin{array}{l}\text { Site Development } \\
\text { Work }\end{array}$ & & & & & & & & & & & & & & & & & & \\
\hline Civil Work & & & & & & & & & & & & & & & & & & \\
\hline $\begin{array}{l}\text { Approval of } \\
\text { Major Drawings }\end{array}$ & & & & & & & & & & & & & & & & & & \\
\hline $\begin{array}{l}\text { Supply of Major } \\
\text { BOS }\end{array}$ & & & & & & & & & & & & & & & & & & \\
\hline $\begin{array}{l}\text { Supply of PV } \\
\text { Modules }\end{array}$ & & & & & & & & & & & & & & & & & & \\
\hline $\begin{array}{l}\text { Civil Work \& } \\
\text { Erection of MMS }\end{array}$ & & & & & & & & & & & & & & & & & & \\
\hline $\begin{array}{l}\text { Installation of all } \\
\text { DC\&AC Circuit }\end{array}$ & & & & & & & & & & & & & & & & & & \\
\hline $\begin{array}{l}\text { Interconnection } \\
\& \text { Testing of } \\
\text { Entire Plant }\end{array}$ & & & & & & & & & & & & & & & & & & \\
\hline $\begin{array}{l}\text { Commwassioning } \\
\text { of Entire Plant as } \\
\text { per SECI }\end{array}$ & & & & & & & & & & & & & & & & & & \\
\hline $\begin{array}{l}\text { Completion of } \\
\text { Facilities }\end{array}$ & & & & & & & & & & & & & & & & & & \\
\hline $\begin{array}{l}\text { COD with SECI } \\
\text { (full capacity) }\end{array}$ & & & & & & & & & & & & & & & & & & \\
\hline
\end{tabular}


Fig.1 Location of Site: Gujarat Solar park, Charnaka, Santalpur

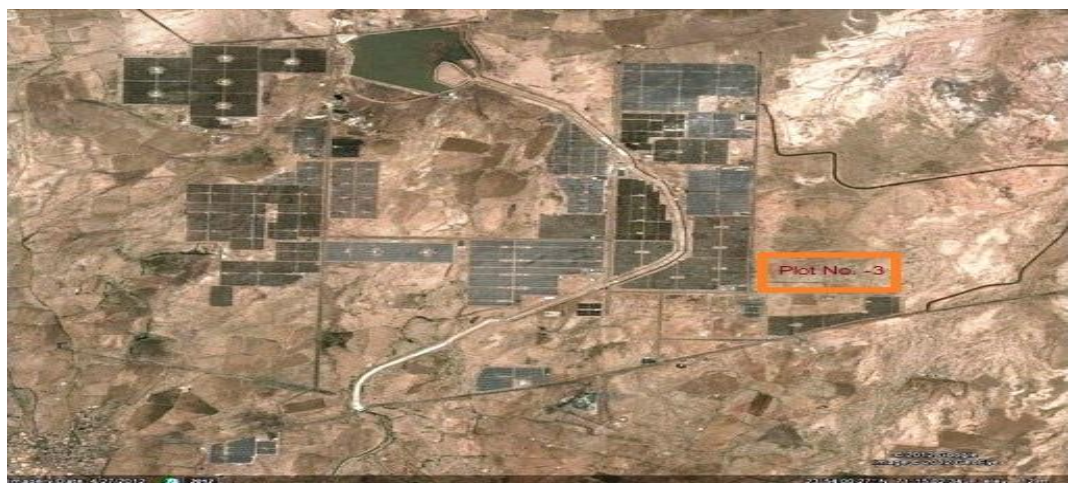

Fig.2 Simulation parameters, main results and loss diagram

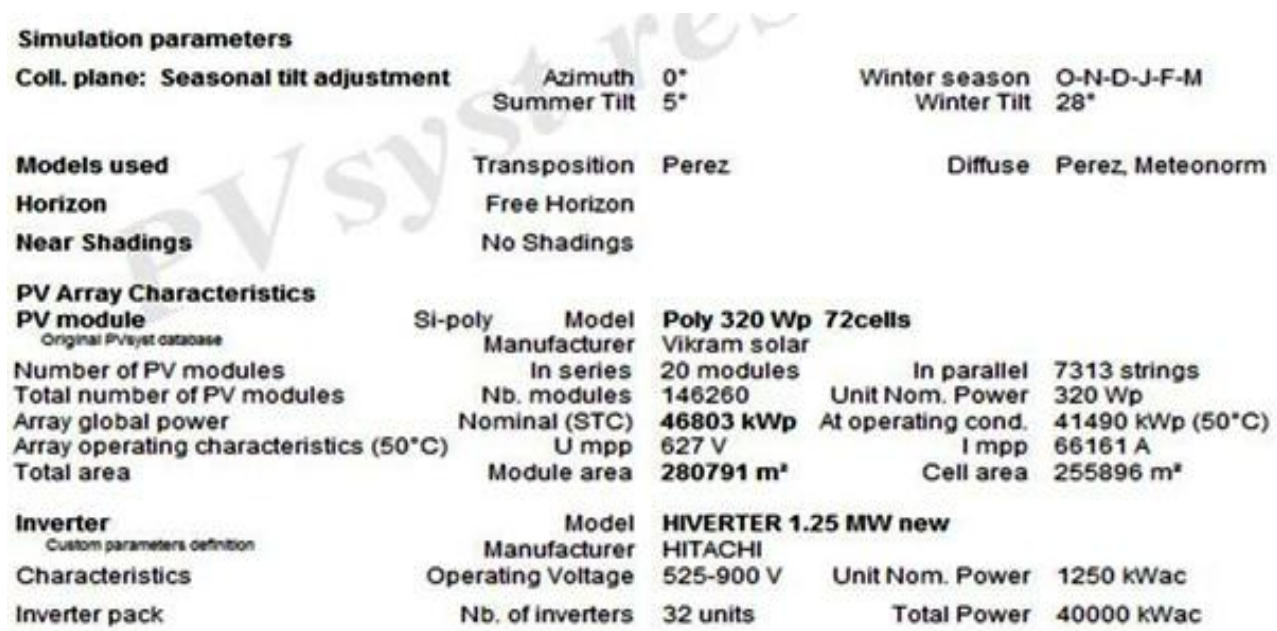

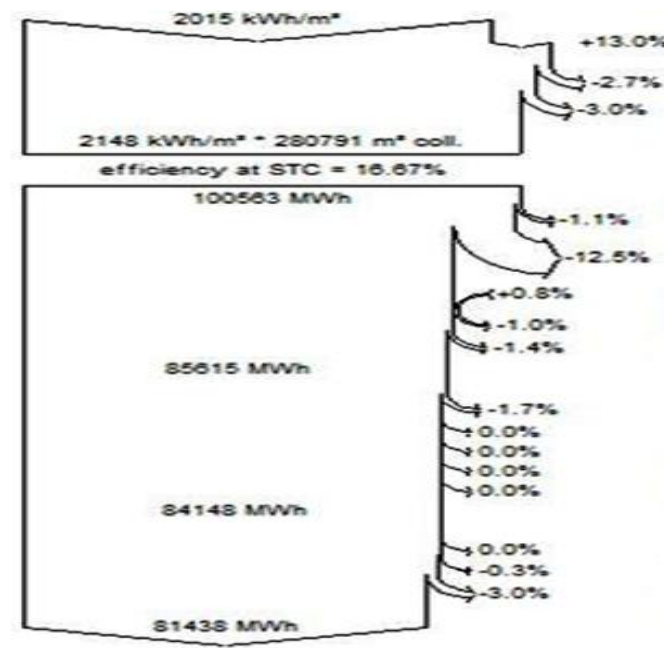

Horizontal global irradiation

LAM factor on global

Solling loss factor

Effective irradiance on collectors

PV conversion

Array nominal energy (at STC effic.

Priss due to imadianoe leve

PV loss due to temperature

Module quality loss

Module array mismatoh loss

Ohmie wiring loss

Array virtual energy at Mpp

Inverter Loss during operation (effiolenoy)

Inverter Loss over nominal inv. power

Inverter Loss over

Inverter Loss due to voltage threshold

Available Energy at Inverter Output

Auxilaries (fans, other)

AC ohmic loss

External transfo loss

Energy injected into grid 
Fig.3 Typical activities for solar power plant as per time requirements

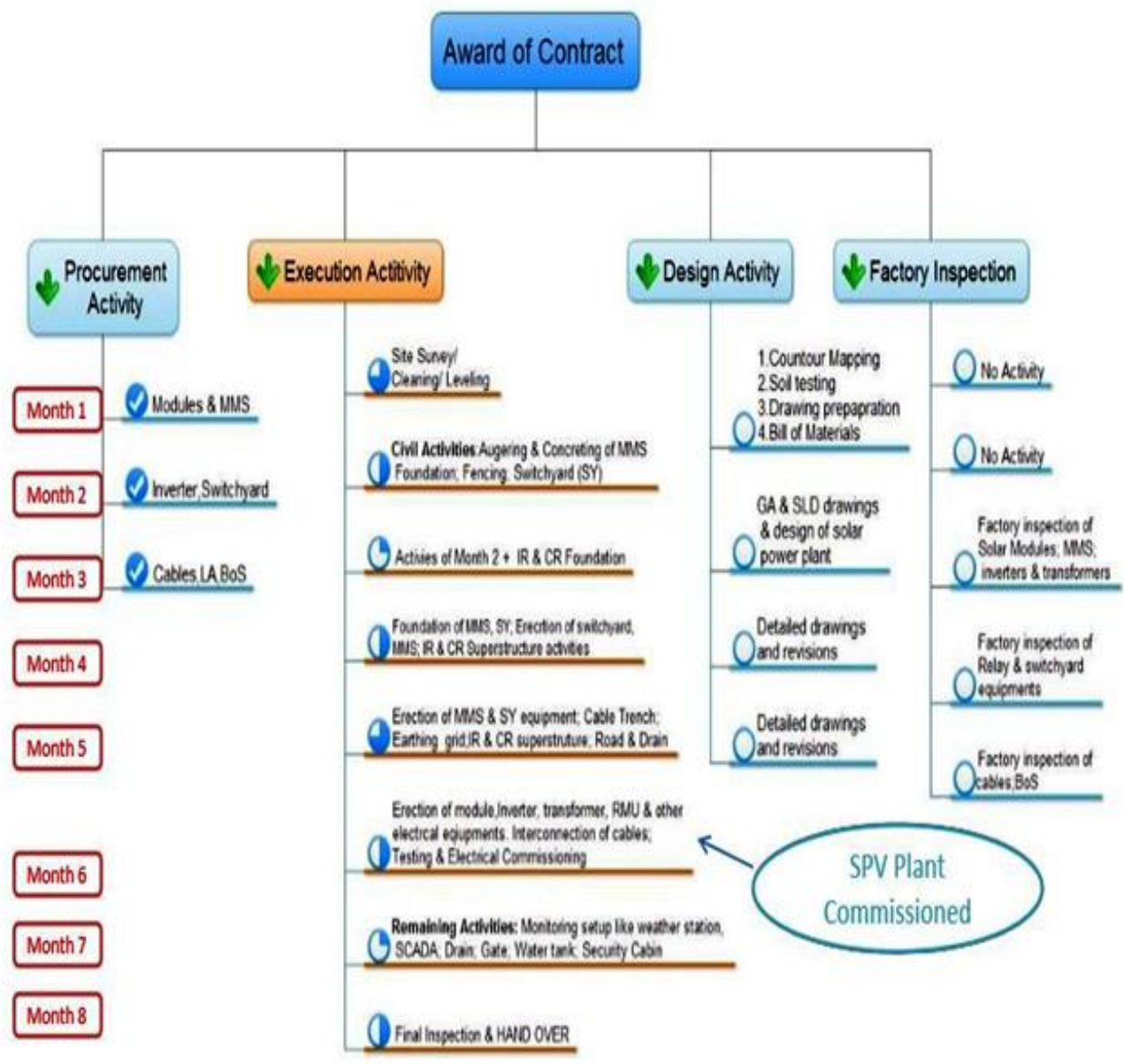

Challenges and solution in solar project execution

As per the EPC contract terms, the project was to be setup within 242 days from the date of signature of the contract. This timeframe created its own challenges, which Vikram Solar Pvt. Ltd. (EPC Contractor Company) was not able to overcome successfully. The plant was commissioned 93 days after the scheduled commissioning date.

Above chart shows the Completion Schedule (COD with SECI) of $40 \mathrm{MW}$ Solar Power Project of Plot No.3 at Gujarat Solar Park. The green color shows the real schedule time period of $40 \mathrm{MW}$ Solar Power Project and the red color show delay time in completion of project. The large volume of and quantum work involved in the solar project.

Supply of Materials: EPC Contractor Company did not tape into its network of trusted, reliable suppliers to ensure timely delivery of all materials and components. This was not well synchronized with the site construction work so that each stage could not be executed on-time.

Pre-engineered structures: If EPC Contractor Company used pre-engineered structures and also included pre-cast foundations for transformers and inverters so they can reduce on-site construction work and accelerated the 
entire process. The level of standardization also ensured higher execution quality.

Plant construction: EPC Contractor Company adopted a construction process in which the entire plant was segregated into different blocks. Specialized teams were formed to complete different construction tasks associated with each block.

In conclusion, solar Power Project consists of certain tasks that have a beginning and an end, constrained by schedules and objectives that must be executed within the limits of date and budgets. Failure to comply with any of these requirements will usually result in the contractor having to pay financially compensation to the owner in the form of Liquidated damages (LDs). Project management is a methodology and a discipline required for planning, organizing, and managing project manpower and resources. This is a prerequisite for successful completion of a project. Project management may also aim to for continuous improvement in performance over the life of contract. There are a number of common issues that may arise during the construction phase. Most of this can be avoided through appropriate design, monitoring, quality control and testing onsite.

\section{References}

Utility Scale Solar Power Plants - A Guide for Developer's And Investors, International Finance Corporation A Member of World Bank Group, February 2012.

"Renewable Energy Technologies: Cost Analysis Series"; Solar Photovoltaics Volume 1: Power Sector Wassue4/5; June 2012.

Utility Scale Solar Power Plants - A Guide for Developer's Guides, International Finance Corporation A Member of World Bank Group, 2015.

SAPC Best Practices in PV System Installation Version 1.0, March 2015 Period of Performance October 2014 September 2015.

Source: State wise estimated solar power plant potential in the country; Document No: 22/02/2014/SolarR\&D(Misc); Govt. of India; MNRE.

\section{How to cite this article:}

Gohil, K.H., V.V. Modi, GoraAlok, N.N. Desai, Ramesh Harajibhai Chaudhari, V.M. Modi and Hitesh Chaudhary. 2019. Technological Study on Project Management Activities of Epc Solar Pv Power Plant. Int.J.Curr.Microbiol.App.Sci. 8(04): 757-763. doi: https://doi.org/10.20546/ijcmas.2019.804.083 